\title{
超微細粒組織を活用した 1800MPa 級超高強度鋼のき裂伝播挙動 (微視組織制御からの破壊制御の構築)
}

\author{
井上 忠信 ${ }^{* 1}$ ，木村 勇次 ${ }^{* 1}$ ，邱 海 ${ }^{* 2}$ ，王 成鐸*3
}

\section{Mechanism of crack propagation in $1800 \mathrm{MPa}$ class ultrahigh-strength steel by ultrafine-grained structure (Development of fracture control from microstructure design)}

\author{
Tadanobu INOUE ${ }^{* 1}$, Yuuji KIMURA*1, Hai QIU² ${ }^{* 2}$ and Chengduo WANG ${ }^{* 3}$ \\ ${ }^{*} 1,{ }^{*},{ }^{* 3}$ National Institute for Materials Science \\ 1-2-1 Sengen, Tsukuba-shi, Ibaraki 305-0047, Japan
}

\section{Received 19 May 2015}

\begin{abstract}
A 1800 MPa class steel bar with an ultrafine elongated grain (UFEG) structure was fabricated by multipass caliber rolling at $500^{\circ} \mathrm{C}$. The static three-point bending test was conducted in a temperature range from $100^{\circ} \mathrm{C}$ to $-196^{\circ} \mathrm{C}$. The behaviors of crack propagation on the developed steel were studied on the basis of the microstructural features. The conventionally quenched and tempered steel with a martensitic structure showed a catastrophic fracture behavior which fractured with a peak bending load in a temperature range from $23^{\circ} \mathrm{C}$ to $-196^{\circ} \mathrm{C}$. The crack propagated directly across the center portion of the test bar. On the other hand, the developed steel exhibited a noncatastrophic fracture behavior with evidence of stepwise load increases beyond the first load drop. The microcrack occurred, from near the notch root, with normal to the loading direction (LD) or with an angle of $45^{\circ}$ to the LD, and the crack propagated with many zigzag cracks branching from the zigzag crack along the longitudinal direction of the test bar. The occurrence of such brunching cracks corresponded to the spatial distribution of $\{100\}$ cleavage planes and boundaries of the elongated grains. Namely, the microstructural damage is not localized but rather is widely distributed over very large dimensions. In the bending load - displacement curve, many load drops appeared, and the bending load did not decrease with an increase in displacement due to two effects: the stress shielding effect associated with the interference of multiple cracks and the effect of the improved plastic deformation associated with grain refinement and texture.
\end{abstract}

Key words : Iron and steel, Toughening mechanism, Crack propagation, Crystal refinement, Microstructural control

\section{1. 緒言}

希少合金元素の枯渇や資源循環型社会の醸成を背景に，合金設計に基づく材料開発から，プロセス設計に基づ く材料開発一の転換が期待されている(原田，河西，2010，矢田，1996). 鉄鋼を始めアルミニウム合金やマグネ シウム合金など，様々な金属材料の組織を微細にして機械的特性を向上させる研究が活発に行われている(Inoue, et al., 2009a). その中で, 鉄鋼材料は合金成分と加工熱処理を組み合わせることで約 200MPa〜 4GPa 程度までの広 範囲の引張強度をカバーできる万能かつコストパフォーマンスに優れた構造用金属材料である. しかし，数千年 以上の歴史を有寸る鉄鋼材料においても，高強度化とともに勒性，疲労などの破壊特性が低下寸ることから，そ の適用範囲が限定されているのが現状であり，この点をブレークスルーするための組織設計アイデアが求められ

No.15-00281 [DOI:10.1299/transjsme.15-00281], J-STAGE Advance Publication date : 16 September, 2015

*1 正員, 物質・材料研究機構（テ305-0047 茨城県つくば市千現 1-2-1）

*2 物質 $\cdot$ 材料研究機構

*3 物質・材料研究機構 (現 鄭州大学)

E-mail of corresponding author: INOUE.Tadanobu@nims.go.jp 
てきた.

複数の素材を接合・結合させて創製する複合材料やラミネート材，クラッド材では，静的および動的な破壊試 験において, き裂が荷重方向とほぼ直角に分岐する層状破壊を示し, 勒性が改善することが報告されている(例え ば，Kum, et al., 1983).これは，層状破壊によってき裂先端が鈍化し，破壊を支配するプロセスゾーンの応力 3 軸 度（塑性拘束度）が変化するためであり，き裂の発生よりもき裂の進展を如何に抑制するかが勒性向上の設計思 想となっている，我々はこれまでに塑性加工プロセスによって結晶粒の形態（粒径と粒形）と方位を制御し，層 状破壊を意図的に発現させることで，低・中炭素低合金鋼の強度一勒性バランスを飛躍的に向上させることに成 功してきた(Kimura, et al., 2008, Inoue, et al., 2009b, 井上，木村， 2013). これは，高強度化によってより顕在化す る脆弱面を逆利用して，まず微視き裂を生じさせ，その後成長した主き裂の周辺に多数の微細き裂を同時多発的 に発生させることで, 主き裂先端の応力を緩和し力を分散させた応力遮蔽効果（破壊駆動力を低下させる）と共 に，材料自体が完全に壊れない方向に主き裂を誘導することを設計思想としたものである．すなわち，(100)へき 界面, 結晶粒界, 炭化物等の硬質第 2 相, そして基地組織と第 2 相組織の界面等の弱い場所の空間分布を制御寸 る設計思想で材料の破壊を制御することを試みた。このような思想に基づいた高強度鋼は，たとえ想定外の力が 作用しても材料自体は完全には脆性破壊しにくいような機能をもたせることが可能であると考える．この破壊に 対する高い抵抗力はき裂の伝播挙動によるものであるが，この点についての検討は十分には行われていない.

本論文では， $500^{\circ} \mathrm{C}$ 焼戻しによって室温で $1800 \mathrm{MPa}$ の引張り強度が得られるように合金設計した中炭素低合 金鋼を対象に，溝ロール圧延による加工ひずみ制御によって超微細䋐維状結晶粒組織を有する棒材を創成し，引 張り試験， 3 点曲げ試験，そしてデジタル顕微鏡（Digital Microscope; DM）, 走査電子顕微鏡 (Scanning Electron Microscope; SEM), 電子線後方散乱回折 (Electron Backscatter Diffraction Pattern; EBSP) による組織観察を通じて, 初期ノッチ底からのき裂伝播挙動と組織の関係について検討を行った。

\section{2. 実験方法}

\section{$2 \cdot 1$ 溝ロール圧延における材料創製}

供試材として，低合金鋼成分で 1800MPa 級の超高強度を実現できるモデル合金として，0.39\%C-2\%Si-0.2\%Mn$1 \% \mathrm{Cr}-1 \% \mathrm{Mo}$ の鋼を用いた。 まず， $40 \mathrm{~mm}$ 角， $120 \mathrm{~mm}$ 長さの角材に $1200^{\circ} \mathrm{C} て ゙ ~ 1 \mathrm{~h}$ 溶体化処理を施し，熱間圧延で 約 $30 \mathrm{~mm}$ 角の棒材とした後水焼入れした. 次に, 焼入れ材を $500^{\circ} \mathrm{C}$ で $1 \mathrm{~h}$ 焼戻した後, 図 $1(\mathrm{a})$ に示すスクエア孔型 を有する溝ロール圧延(Inoue, et al., 2007)によって約 14mm 角, 約 1000mm 長さ（減面率 78\%に相当）の棒材とし 室温まで空冷した (以後, TF 材と呼ぶ)。 また, 約 $14 \mathrm{~mm}$ 角の棒鋼を $950^{\circ} \mathrm{C} て ゙ ~ 0.5 \mathrm{~h}$ オーステナイト化後油焼入れ し, $500^{\circ} \mathrm{C}$ で $1 \mathrm{~h}$ 焼戻後水冷して得られた棒材を比較材として用いた（以後, QT 材と呼ぶ)。このときの旧才ース テナイト $(\gamma)$ 粒径は約 $50 \mu \mathrm{m}$ であった. 試料座標系は, 図 1 に示すように, 棒材の長手方向, 寸なわち圧延方



\section{$2 \cdot 2$ 組織と機械的特性}

引張りおよび 3 点曲げ試験片は, 各棒材の中央から採取し, 試験は, (株島津製作所オートグラフ AG-10TDを 用いて行った．図1(b)に棒鋼からの試験片採取と引張り方向および押込み荷重方向（LD）の関係を示す. 引張り 試験は, 直径 $6 \mathrm{~mm}$, 平行部長さ $30 \mathrm{~mm}$ の丸棒試験片（JIS14A 試験片）について, $0.85 \mathrm{~mm} / \mathrm{min}$ のクロスヘッド速 度一定（初期ひずみ速度 $5 \times 10^{-4} / \mathrm{s}$ ） で実施した。 3 点曲げ試験は, 図 2 に示したように $10 \mathrm{~mm}$ 角 $\times 55 \mathrm{~mm}$ 長さの 試験片を対象に，スパン長さ $40 \mathrm{~mm}$, 押込み速度 $0.5 \mathrm{~mm} / \mathrm{min}$ の変位制御で, 1 条件の試験数 $1 \sim 4$ にて実施した. $\mathrm{TF}$ 材の組織的特徵から疲労予き裂が分岐し, 初期き裂を安定的に導入できないことが考えられたため, $0.1 \mathrm{~mm}$ 径 ワイヤーを用いた放電加工で深さ $5 \mathrm{~mm}$ ，先端曲率半径 $0.13 \mathrm{~mm}$ （実測值）の初期ノッチを導入した．ノッチ先端 は，棒鋼断面中心に位置付くように加工を行った(Inoue and Kimura, 2013). 3 点曲げ試験後の外観やマクロ破面 は, DM（KEYENCE VHX-900）やデジタルカメラによって，ミクロ破面はSEM（KEYENCE VE-7800）によっ て観察した. また, 各棒鋼の RD および LD に垂直な断面上の中心近傍について, SEM による組織観察と EBSP による結晶方位測定を行った。 
(a)

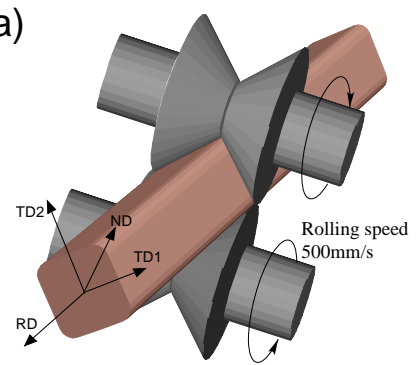

(b)

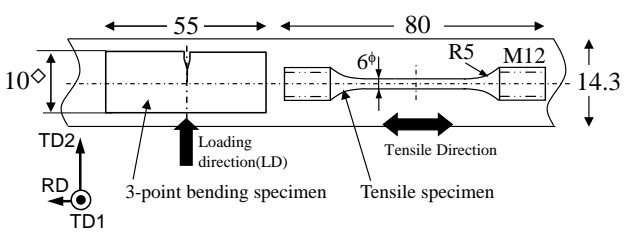

Fig. 1 Schematic drawings of (a) the caliber rolling used in the present study and (b) test pieces taken from the rolled-bar.

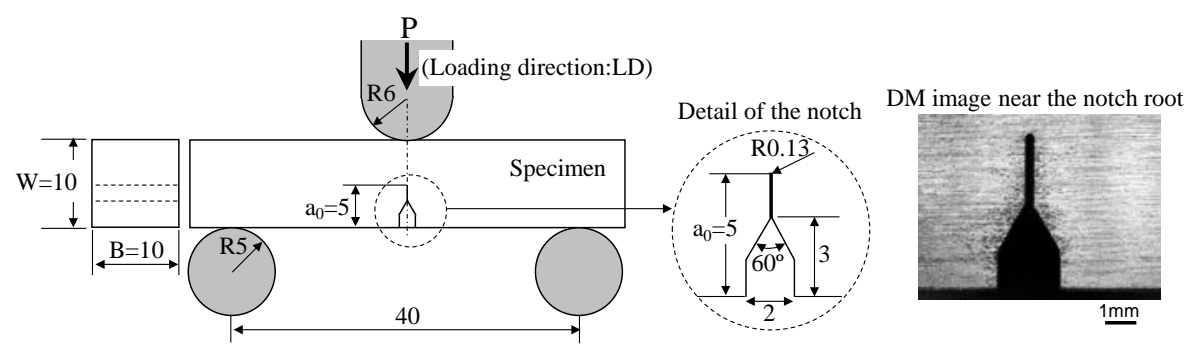

Fig. 2 Shape and dimensions of three-point bending test and DM image near the notch root of the test specimen after electro-discharge machining.

\section{3. 結 果}

\section{$3 \cdot 1$ 超微細織維状結晶粒組織}

図 3 は，TF 材の EBSP による組織観察結果を逆極点図と共に示す(Inoue, et al., 2011). TF 材は，RD に伸張した 超微細な繊維状のフェライト粒組織（平均短軸径は約 $310 \mathrm{~nm}$ ）を有し，かつ強い $\alpha$ ファイバー集合組織 （RD//<110>） を伴う. 逆極点図より，特に $\{110\}<110>$ と $\{100\}<110>0$ 結晶方位が発達していることがわかる. なお，TEM 観察の結果から，基地中に $50 \mathrm{~nm}$ 以下のナノ炭化物粒子が球状に分散していることを観察している (Kimura, et al., 2008).この組織は, LD とは垂直および $\pm 45^{\circ}$ 方向に $\{100\}$ へき開面，垂直方向に結晶粒界を多く含 むのに対し，LD とは平行に $\{100\}$ 面をほとんど持たない組織的特徽を持つ. なお，材料の残留ひずみに相当する

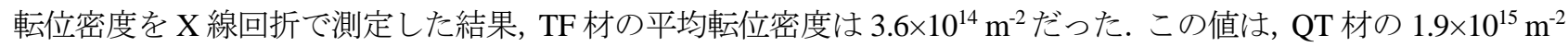
に比べ低かった（Kimura and Inoue, 2013）
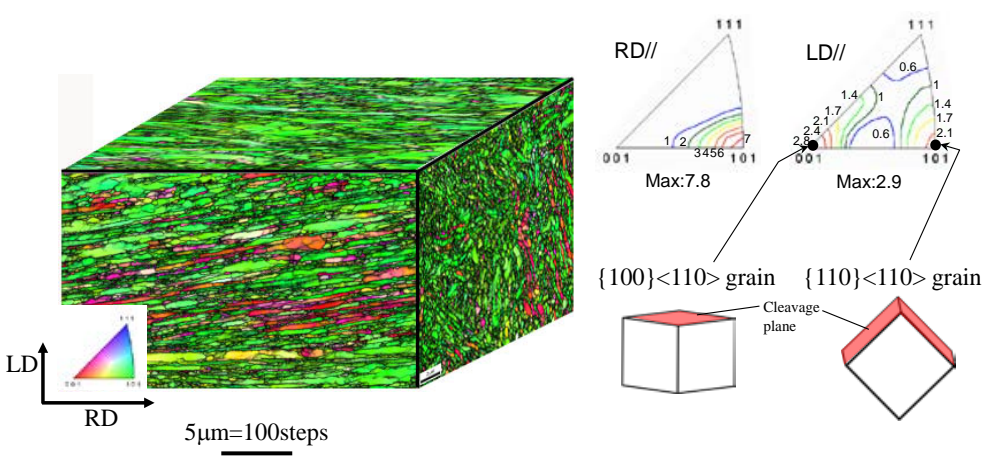

Fig. 3 Three-dimensional orientation maps along the RD and inverse pole figures for RD and LD of TF sample. Here, grain boundaries with misorientation above $5^{\circ}$ are shown.

\section{$3 \cdot 2$ 引張り特性}

図 4(a, b)は, QT 材および TF 材の応力ーひずみ線図を示す. QT 材は焼戻しマルテンサイトの典型的なラウン ドカーブを示し，絞り RA は $150^{\circ} \mathrm{C}$ で $41 \% ， 23^{\circ} \mathrm{C}$ で $31 \% ，-100^{\circ} \mathrm{C}$ で $27 \% ，-196^{\circ} \mathrm{C}$ で $4 \%$ とな，温度と共に著しく 低下した. 一方, 強い $\mathrm{RD} / /<110>$ 方位を持った超微細繊維状結晶粒組織を有する $\mathrm{TF}$ 材は, 微細粒材の特徽の一つ である変形初期に降伏点降下が観察され, かつ高い降伏比を示した. 降伏点降下現象は, 温度 $150^{\circ} \mathrm{Cで}$ 消失した. 


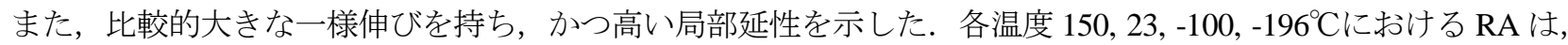
48\%, 47\%, 47\%, 39\%であった. TF 材およびQT 材の温度と降伏応力 YS の関係を図 4(c)に示す．ここで，YS は 0.2\%耐力に相当する. TF 材の方が QT 材よりも大きいが, どちらも温度の低下とともに YS は直線的に増加し, $-100^{\circ} \mathrm{C}$ 以降でより増加する傾向を持つ，両材の温度依存性に大きな相違は見られないが，温度低下による強度向 上は TF 材の方が大きい.

(a)



(b)

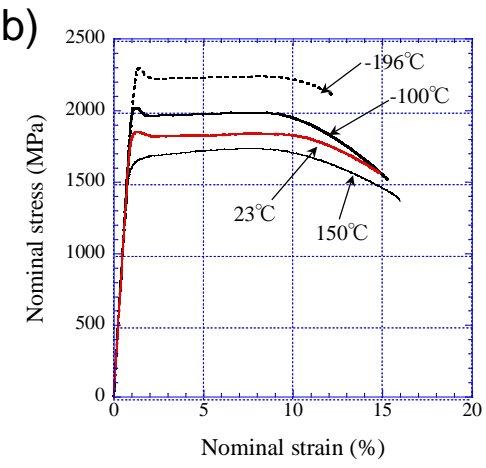

(c)

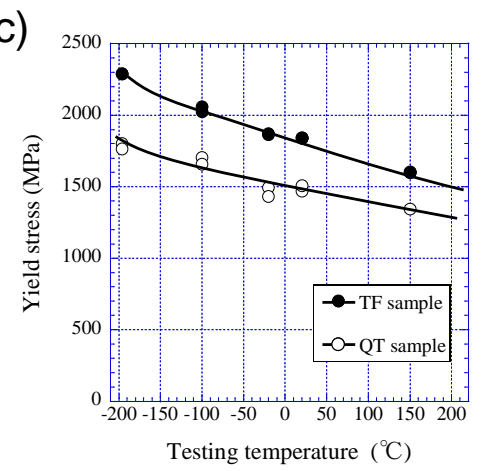

Fig. 4 Stress - strain relations at various temperatures in (a) QT and (b) TF samples, and (c) variations of yield strength, i.e., 0.2\% proof stress with temperature in the TF and QT samples.

\section{$3 \cdot 33$ 点曲げ特性}

図 5 は, $\mathrm{QT}$ 材および $\mathrm{TF}$ 材の曲げ荷重 $P$ と変位 $u$ の関係および $23^{\circ} \mathrm{C}$ 試験後の外観を示す， $\mathrm{QT}$ 材は，典型的な 脆性破壊挙動を示し，最大曲げ荷重 $P_{\text {max }}$ （図 5(a)の矢印）で直ちにき裂が LD と平行に伝播して真二つに破断す る通常の壊れ方をした，破断荷重に相当する $P_{\max }$ は，温度とともに低下しているのがわかる，一方，図 5(b, c)に 示した $\mathrm{TF}$ 材では荷重 $P_{1}$ で小さな荷重低下が生じ，その後，多数の小さな低下を伴いながら荷重が増加し，最後

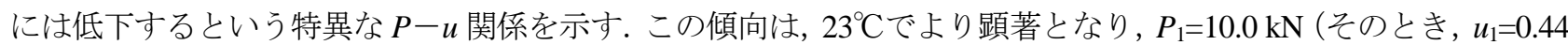
$\mathrm{mm}$ ）後，荷重は $P_{\max }=14.0 \mathrm{kN} （ \mathrm{u}=7.4 \mathrm{~mm}$ ）まで増加し続けた。試験片外観写真から，主き裂が荷重方向とは直角

（すなわち試験片長手方向）に伝播する層状破壊を起こしているのがわかる. なお，試験片は- $80^{\circ} \mathrm{C}$ 以上の温度で は試験片厚さに相当する量を押込んでも破断しなかったため，これらの場合は $10 \mathrm{~mm}$ 押込んだ時点で試験を中断

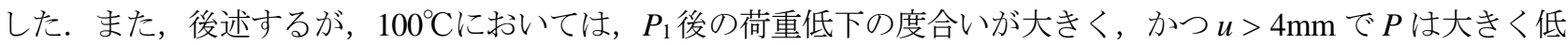
下寸る。これは，き裂伝播挙動に延性破壊の寄与が大きくなっているためである.

(a)

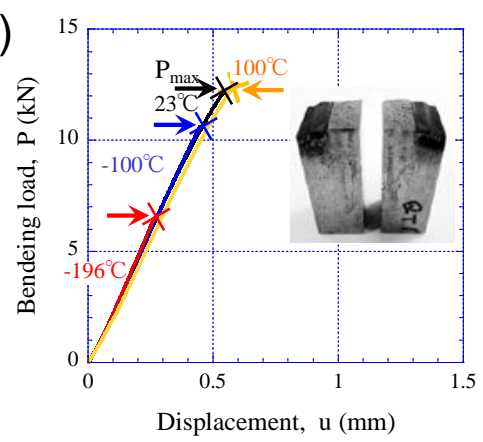

(b)

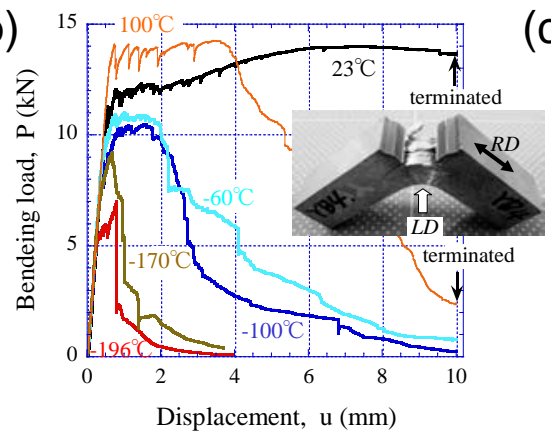

(c)

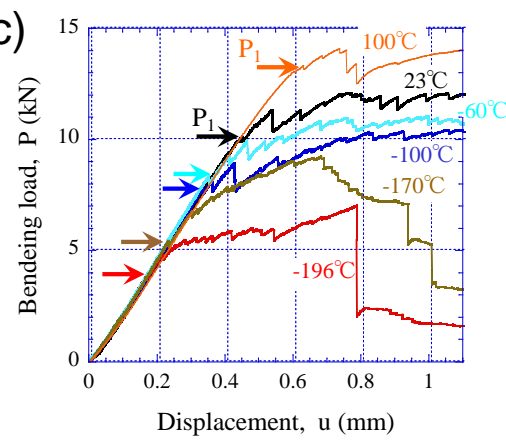

Fig. 5 Bending load, P, versus displacement curve, $\mathrm{u}$, at various temperatures in (a) QT and (b) TF samples. Here, photographs in (a) and (b) denote appearance of samples after bending test at ambient temperature. (c) P - u curves at first stage of (b).

図 6(a)は，曲げ試験で最初に荷重低下したときの荷重 $P_{1} （ \mathrm{QT}$ 材では $P_{\max }$ ） と押込み変位 $u_{1}$ の関係を QT 材お よびTF材の全温度データについて示したものである. 試験温度 $23^{\circ} \mathrm{C}$ 以下では $P_{1}-u_{1}$ は線形関係を満たしており， 初期き裂が脆性的に発生していることがわかる。試験温度 $100^{\circ} \mathrm{C}$ において，両材材とも線形関係より多少低い $P_{1}$ となっており，初期き裂発生に，延性き裂が寄与していることが示唆される．図 5(a, c)から， $\mathrm{P}_{1}$ 前に $\mathrm{P}-\mathrm{u}$ の非線 
形関係が現れており，ノッチ底の塑性変形領域が最初の荷重低下に影響を及ぼしている可能性がある．そこで， 最初の荷重低下が脆性き裂で生じた $23^{\circ} \mathrm{C}$ 以下での $P_{1}$ と温度の関係をまとめた結果を図 6(b)に示寸. 押込み变位 $u$ とともに増加した $P_{1}$ には多少のバラツキもあったが, 各温度において $\mathrm{u}_{1}$ のバラツキは $0.05 \mathrm{~mm}$ の範囲であり, 図6(b)からわかるように両材とも温度とともに $P_{1}$ は同様な傾向で減少した.

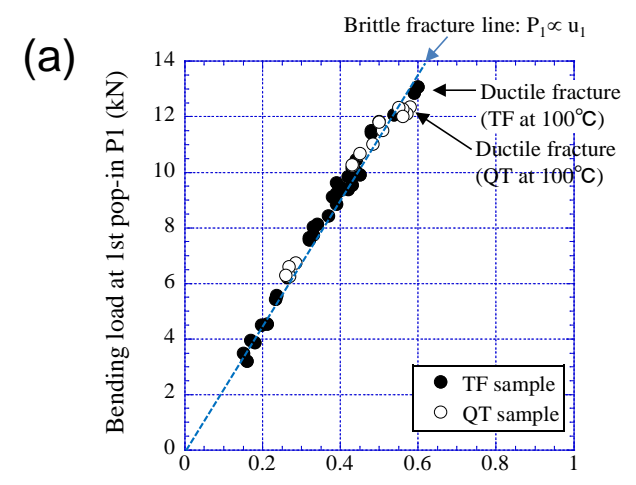

(b)

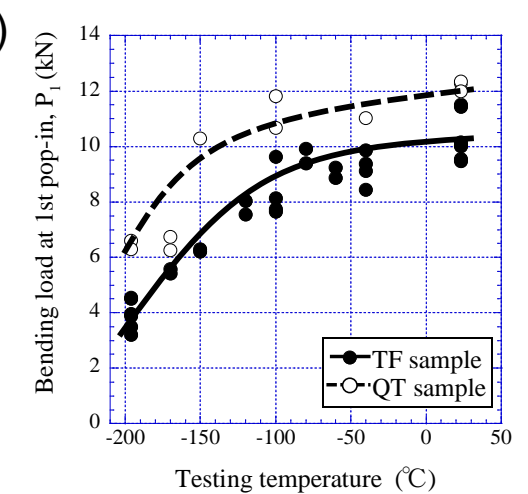

Fig. 6 Relations between (a) bending load, $\mathrm{P}_{1}$, and displacement, $\mathrm{u}_{1}$, at first pop-in and (b) variations of $\mathrm{P}_{1}$ with temperature in the TF and QT samples.

\section{4. 考 察}

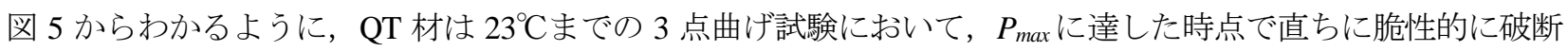
する，一方， $\mathrm{TF}$ 材は層状破壊を引き起こし， $\mathrm{P}_{1}$ 後も壊れることなく荷重が増加し，その後緩やかに低下寸る．す なわち, TF 材は超高強度であっても脆性破壊的に破断しない機能を有する．この機能は，ノッチ底近傍での初期 き裂発生後, 主き裂が分岐し, 長手方向に進展することで発現する. そこで, 初期き裂発生後の伝播挙動と組織 の関係について検討を行った。

\section{$4 \cdot 1$ 焼入れ焼戻し材（QT 材）}

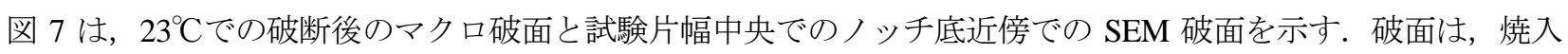
れ焼戻し材の典型的な擬へき開である. 点線で囲んだ約 $20 \mu \mathrm{m}$ のファセットがへき開破壊の有効結晶粒径と思わ れる. 図 8 は, $-40^{\circ} \mathrm{C}$ おび $-196^{\circ} \mathrm{C}$ で SEM 破面を示す. 温度の低下とともに延性のあるティアリッジの存在領 域は少なくなるが，へき開ファセットの大きさはほぼ同じであることがわかる，一般的に，焼入れ焼戻しマルテ ンサイトの破壊の有効結晶粒径 $d_{\text {eff }}$ はパケット径であり (三村, 町田, 2005, Morris, et al., 2003), 材料はパケット 内の多数のブロック (ラス束) と交差した(100)へき界面に沿って脆性的に破断する. 焼戻しマルテンサイトのよ うな複雑な階層構造を持つ鋼は, $P$ と $u$ が直線的関係を持ち，マクロ的には脆性的に破壊をしていても，ミクロ 的にはティアリッジも観察される. これらティアリッジは, 局所的な脆性破壊を発端として付随的に発生したも のであり，QT 材は脆性的に破壊していると判断できる.

(a)

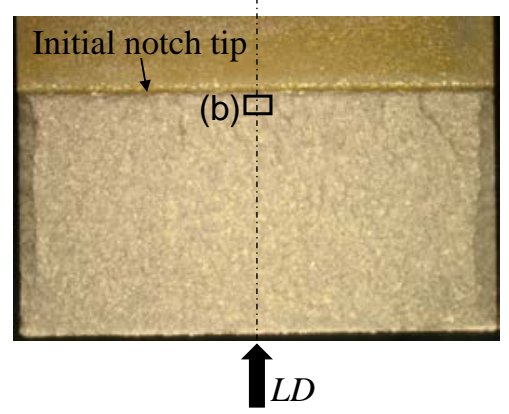

(b)

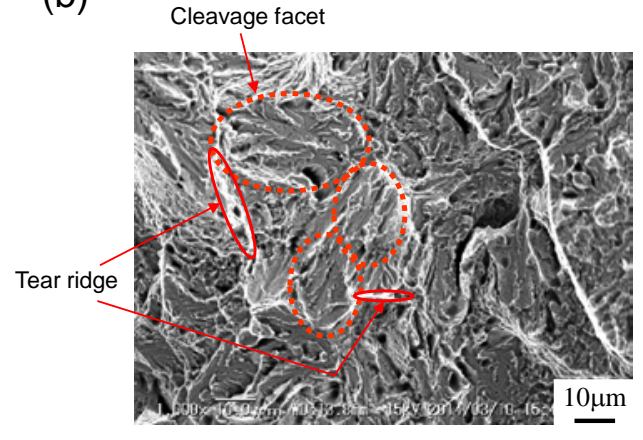

Fig. 7 (a) Fracture surface of the QT sample after bending test at ambient temperature and (b) SEM image at local site near initial notch. 
(a) $-40^{\circ} \mathrm{C}$

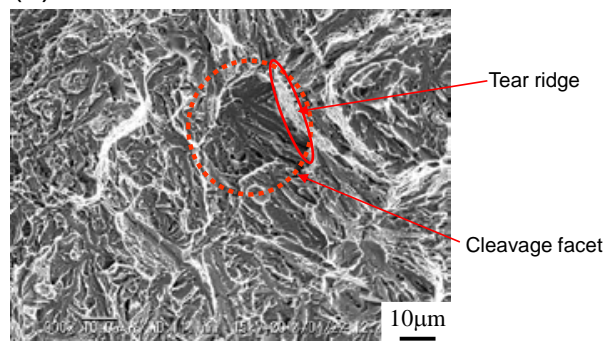

(b) $-196^{\circ} \mathrm{C}$

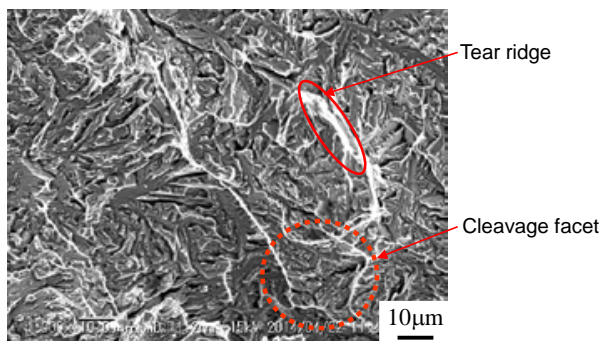

Fig. 8 SEM images near initial notch of the QT sample after bending test.

\section{$4 \cdot 2$ 超微細繊維状結晶粒材（TF 材）}

図 9(a)は $23^{\circ} \mathrm{C} て ゙ ~ u=10 \mathrm{~mm}$ 押込んだ後の TF 材の試験片中央断面上のマクロ写真, 図 9(c)は- $170^{\circ} \mathrm{Cで}$ 破断後の試 験片外観写真, 図 9(b, d)はそれぞれの温度での層状破壊面の SEM 組織を示す。これらの観察結果から, き裂が LD と平行ではない方向に分岐し, 直線的ではなくジグザグに長手方向に進展しているのがわかる. また, 長手 方向に進展した主き裂端近傍では, cracks $\perp$ LD と cracks $\angle 45^{\circ} \mathrm{LD}$ の微小き裂も観察できる. これらのジグザグき

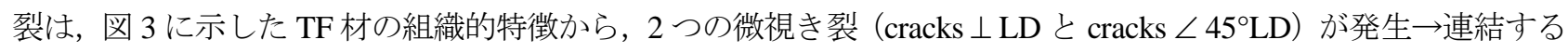
ことで伝播した結果である(Inoue, et al., 2012，Inoue and Kimura, 2013). cracks $\perp$ LD は，\{100\}<110>結晶粒の $\{100\}$ へき界面および結晶粒界に, cracks $\angle 45^{\circ} \mathrm{LD}$ は $\{110\}<110>$ 結晶粒のへき界面に起因するものと考えられる. 破面 観察結果から，ジグザグき裂は RD とほぼ垂直な面(step)における微細ディンプル（図 9(b,d)の矢印部分） と平行 な面(terrace)における擬へき開で構成されている。このような step/terrace の層状破面は, 試験温度が低下しても同 様に観察された。 また，23ㄷ゙゙ノッチ底近傍から発生した微視き裂は主き裂に成長しながらジグザグに RD と ほぼ平行に進展する。一方, 図 9(c,d)からわかるように, 温度が-100다下ではミクロ的には step/terrace のジグ ザグき裂は観察されたが， cracks $\angle 45^{\circ} \mathrm{LD}$ の微視き裂が主き裂に成長することで試験片は二つに破断した．これ は，温度低下による強度向上とともに壊れにくさの機能が失われていくことを意味するものである(Kimura and Inoue, 2013).
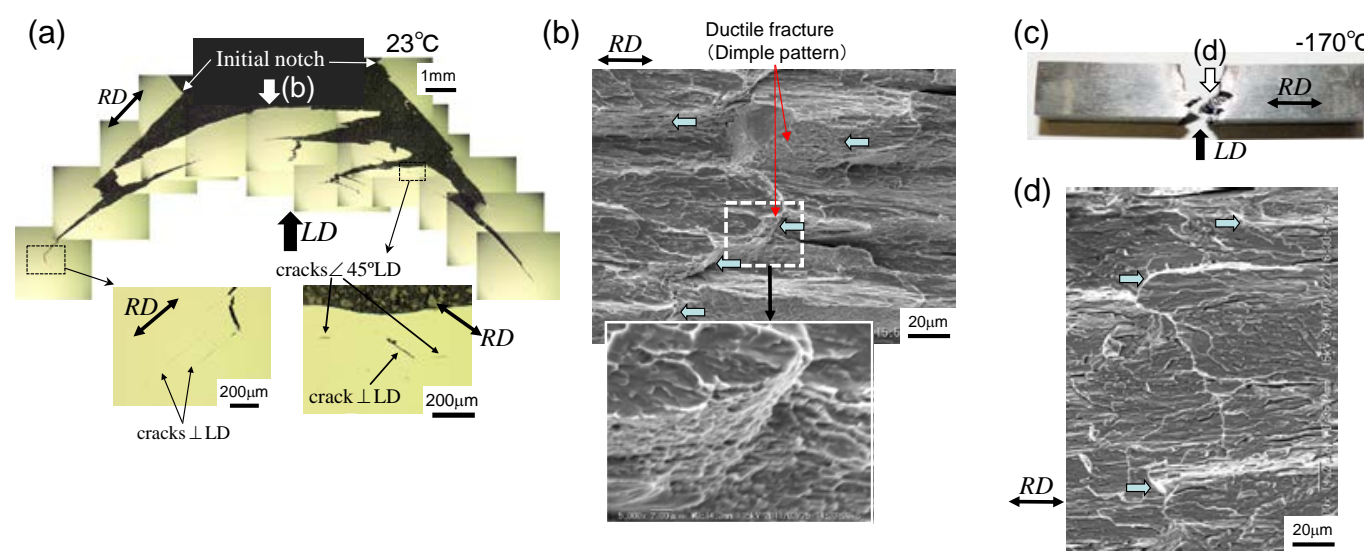

Fig. 9 DM images near the initial notch after bending test at (a) $\mathrm{u}=10 \mathrm{~mm}\left(23^{\circ} \mathrm{C}\right)$ and $(\mathrm{c}) \mathrm{u}=0.23 \mathrm{~mm}\left(-170^{\circ} \mathrm{C}\right)$ of the $\mathrm{TF}$ sample at mid-thickness. (b, d) SEM image of delaminating crack.

き裂の伝播挙動は, ノッチ底近傍での微視き裂の発生箇所に強く依存するので, 試験を途中で止めて, 塑性拘 束度の高い試験片中央断面を追い込み研磨した. 超微細結晶粒により, 微視き裂の最小単位がかなり小さいため,

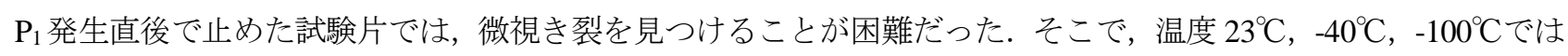
き裂をある程度進展させるため, 幾つかの荷重低下を経た後に試験を停止した. 図 10 は, 各試験温度でのノッチ 底近傍のマクロ写真を $P-u$ 関係とともに示寸。ここで，(a, c , d)は鏡面仕上げままでハイダイナミックレンジ機 
能（RGB 各画素 16bit 階調）を有寸る DM で観察したものであり，(b，e)は薄いエッチング後に SEM 観察したも のである．これらの観察結果から言えることは，微視き裂の発生はノッチ底周辺あるいはノッチ底より $0.1 \mathrm{~mm}$

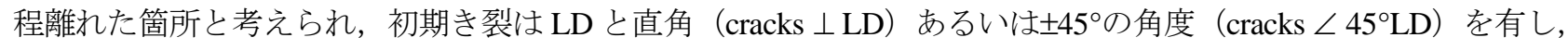
その後ジグザグに長手方向に進展していることが確認できる.

き裂の伝播経路を詳細に観察するため, 図 10(e)のノッチ底周辺に生じた微小き裂の EBSP による組織解析を行 った. その結果を図 11 に示す.ここで, site1, site2 は図 10(e)の拡大図の微小き裂に相当する.この組織結果から, き裂は主に粒界に沿っていることが観察できるが, 超微細結晶粒の粒界やへき界面で分岐しているというよりは, 結晶粒サイズよりも大きな破壊単位で分岐していることが見受けられる.

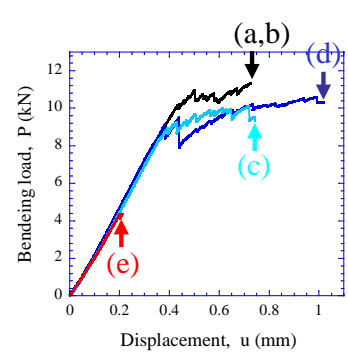

(a) $23^{\circ} \mathrm{C}(\mathrm{u}=0.74 \mathrm{~mm})$

(c) $-40^{\circ} \mathrm{C}(\mathrm{u}=0.75 \mathrm{~mm})$


(d) $-100^{\circ} \mathrm{C}(\mathrm{u}=1.03 \mathrm{~mm})$

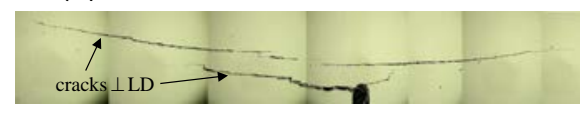

(e) $-196^{\circ} \mathrm{C}(\mathrm{u}=0.21 \mathrm{~mm})$

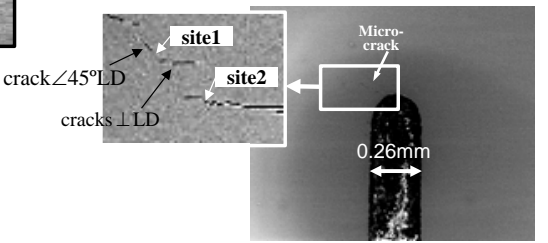

Fig. 10 (a, c, d) DM images and (b, e) SEM images near the initial notch after bending test of the TF sample at mid-thickness.

Site 1

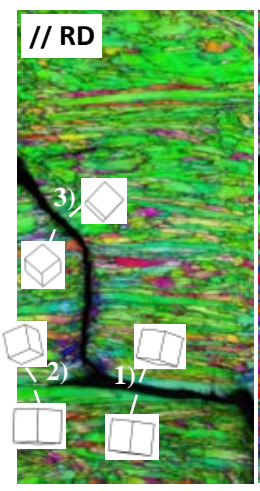

Site 2

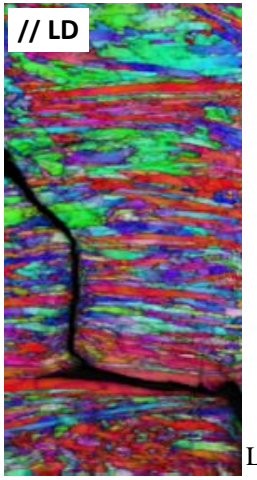

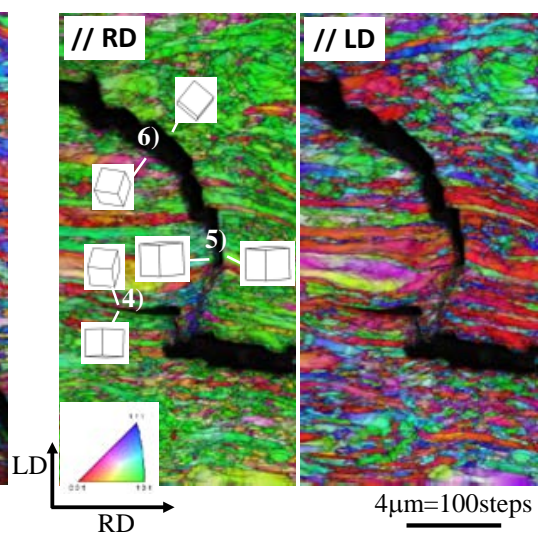

Fig. 11 Orientation maps along the $\mathrm{RD}$ and $\mathrm{LD}$ at the microcracks after first bending load drop , $\mathrm{P}_{1}$, in the TF sample at mid-thickness. Here, site 1 and 2 corresponds to the positions in Fig. 10(e) and 1)-4), 6) are intergranular cracks and 5) is transgranular crack. Grain boundaries with misorientation above $5^{\circ}$ are shown.

\section{4・3 TF 材のき裂伝播経路}

図 10 からわかるように $\mathrm{TF}$ 材の微小き裂は LD と直角あるいは土45の角度で発生し，それらが連結することで 長手方向にジグザグに進展している，微小き裂の発生は，ノッチ底における応力状態に依存し，微小き裂の発生 $\rightarrow$ 進展 $\rightarrow$ 分岐に至る過程で応力状態は逐次変化する．図 2 に示したように，本研究においてノッチ底の曲率は $0.13 \mathrm{~mm}$ であり, 当然初期き裂の発生はノッチや試験片の形状にも依存し, き裂の発生箇所によっては複雑な混 合モード下で生じていることが推測できる.そこで, TF 材の組織異方性を逆利用し, LD と RD が平行な場合(TF90 材と呼ぶ) の 3 点曲げ試験を実施し, モード I 下での微小き裂発生後の伝播経路を観察することで, QT 材とのき 裂伝播挙動の相違を試みた. ただし, 図 1 からわかるように, TF 材は約 $14 \mathrm{~mm}$ 角の棒鋼であり, サンプルサイズ 
を小さくするとノッチ底の塑性拘束やへき開面等の弱い面の存在数が実質減少するため適切ではない. そこで, ノッチ底近傍の組織を変化させない適切な条件を電子ビーム溶接で探索し, 図 12(a)のように TF 材両端を SM490 相当のダミ一鋼と溶接後, 3 点曲げ試験片形状に加工し, 2.2 と同条件で試験を実施した.

図 12(b)は, 試験温度 $23^{\circ} \mathrm{C},-100^{\circ} \mathrm{C},-196^{\circ} \mathrm{C}$ における TF90 材の $P-u$ 関係と $23^{\circ} \mathrm{C}$ 試験後の外観を示す. $\mathrm{LD} / / \mathrm{RD}$ のため, 予想通り TF90 材は QT 材のように $P_{\max }$ で脆性的に破断した. 図 13 は, $23^{\circ} \mathrm{C}$ 試験後の破断面と, $23^{\circ} \mathrm{C}$, $-196{ }^{\circ} \mathrm{C}$ 試験後のノッチ底近傍における SEM 破面を示す. TF90 材の破面は, 図 9(b, d) と同様な step/terrace で構成 される擬へき開の層状破面となり，TF材の長手方向に伝播寸るき裂と同様な形態をしていることがわかる.

(a)

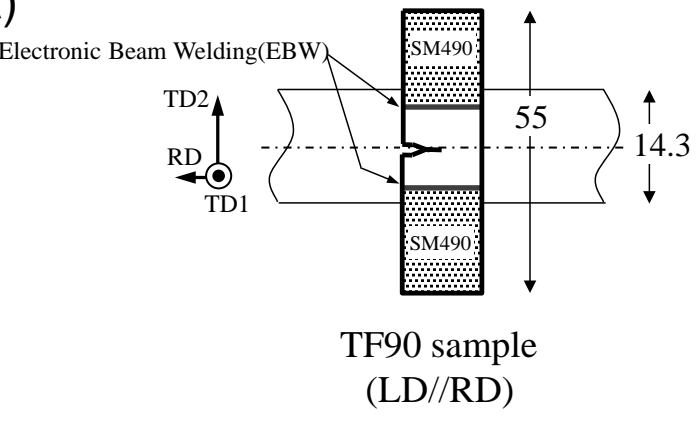

(b)

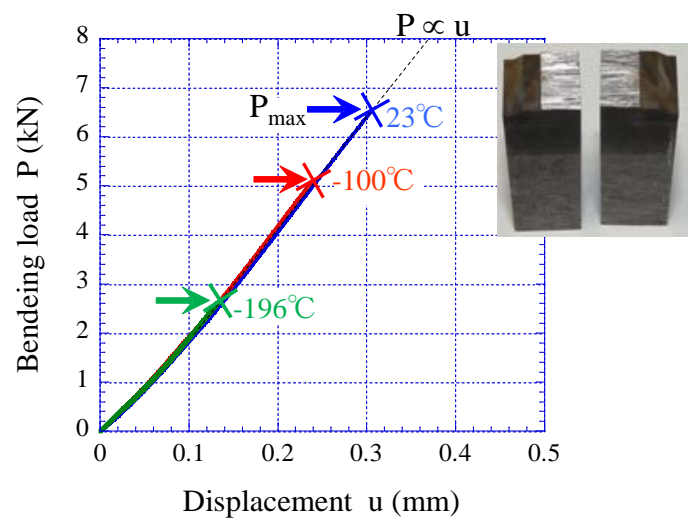

Fig. 12 (a) Schematic illustration of three-point bendind test in the TF90 sample. (b) Bending load P - displacement u relations at various temperatures. Here, photograph in (b) denotes appearance of samples after bending test at ambient temperature.

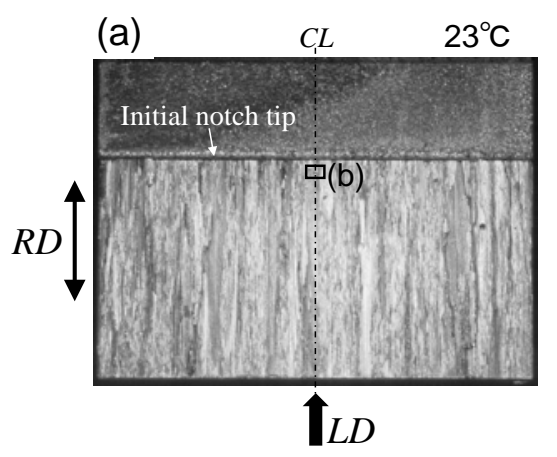

(b)

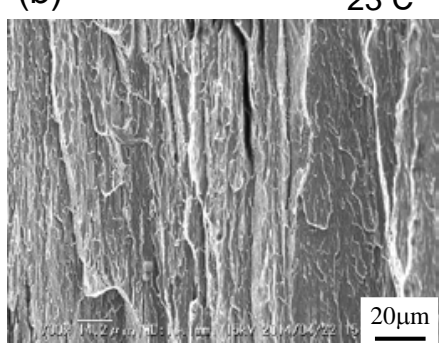

(c)

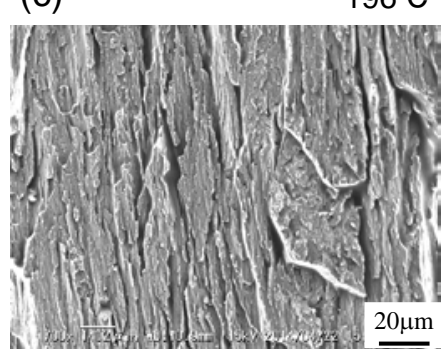

Fig. 13 (a) Fracture surface of TF90 sample after bending test at ambient temperature and (b) SEM images near initial notch of samples after bending test.

図 14 は，QT 材および TF90 材における-196 C C゙の曲げ試験後の中央断面のマクロ写真を示す. 両材ともマク 口的にはき裂はノッチ底から LD と平行に進展し，一部主き裂と平行したき裂も観察された. QT 材のノッチ底か

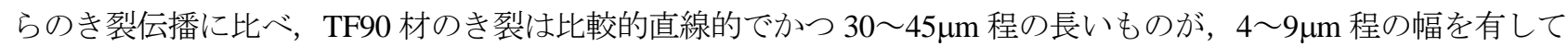
伝播していることが観察できた，QT 材のようなラスマルテンサイトでは，図 15(a)に模式的に示すように旧 $\gamma$ 粒 内の構造が，針状結晶のラス（約 $0.2 \mu \mathrm{m}$ ) やラスが同じ方向に並んで形成されたブロック，幾つかのブロックが 周期的に並んだパケットによって構成され，これら階層的な基地組織中に炭化物粒子が分散している（NIMS，

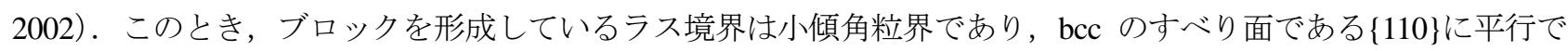
ある，マルテンサイトにおいて，破壊の支配因子となる有効結晶粒径 $d_{\text {eff }}$ はパケット径と考えられ，き裂はパケ ット内のブロックと交差した $\{100\}$ へき界面に沿って進展し, 大傾角粒界のパケット粒界で分岐し, 再び隣接した パケット内の $\{100\}$ 面に沿って進展する.よって，き裂は完全なストレートき裂にならずに，ミクロ的にはジグザ グに進展するはずであり, 図 14(a)からその進展挙動が観察できる.よって, き裂発生に直結する脆性破壊応力を 
向上させるためには，実質的な有効結晶粒径であるパケット径を小さくする，すなわち旧 $\gamma$ 粒を微細にすること が重要となる。しかし，勒性向上を考えた場合，単なる微細化だけでは，発生したき裂を抑制することはできな いため，違う観点からの微視組織の設計が必要となる.

(a) $\mathrm{u}_{\max }=0.26 \mathrm{~mm}, \quad \mathrm{R}_{\mathrm{f}}=6.3 \mathrm{kN}$

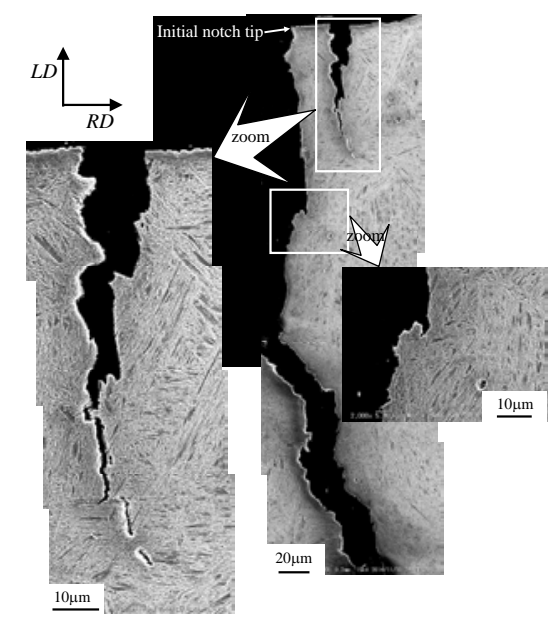

(b) $\mathrm{u}_{\max }=0.13 \mathrm{~mm}, \mathrm{R}_{\mathrm{f}}=2.6 \mathrm{kN}$

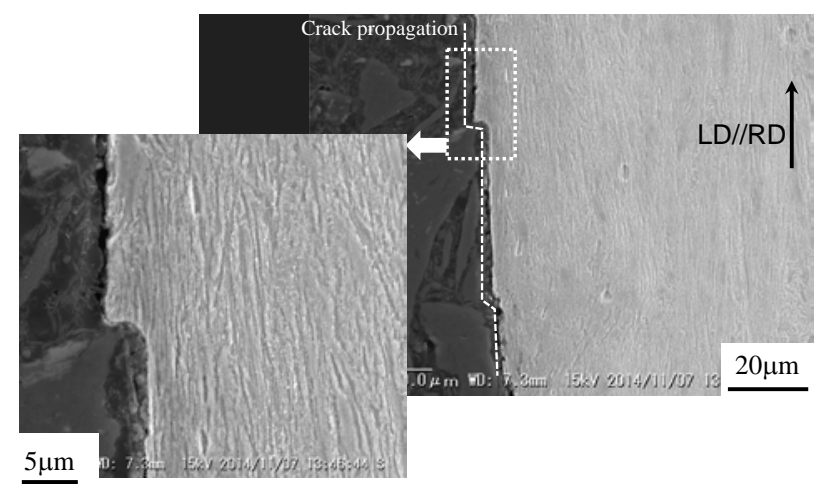

Fig. 14 SEM images of crack propagation near initial notch at mid-thickness after fracture at $-196^{\circ} \mathrm{C}$ of (a) QT and (b) TF90 samples.

(a) Prior austenite grain boundary

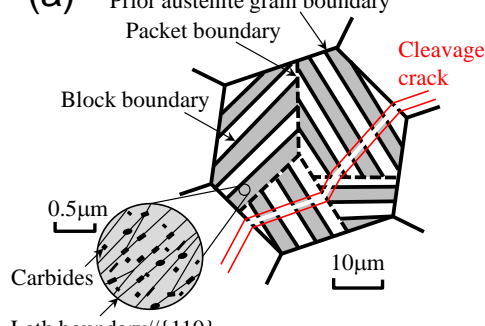

Lath boundary//\{110\} (b)

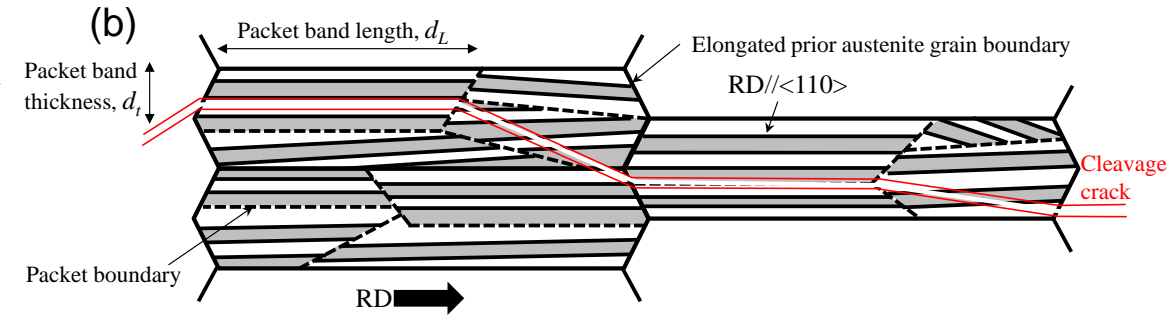

Fig. 15 Schematic illustration on propagation process of cleavage crack in (a) lath martensite (QT sample) and in (b) caliber rolled-microstructure (TF sample) at tempered temperature.

QT 材の旧 $\gamma$ 粒径は約 $50 \mu \mathrm{m}$ ，パケット径は約 $20 \mu \mathrm{m}$ ，ブロック幅は約 $0.5 \mu \mathrm{m}$ であった．図 7(b), 8 に示したへき 開破壊として点線で囲んだものが破壊の最小単位と考えれば， $d_{e f f(Q T)} \approx 20 \mu \mathrm{m}$ であり，本論文においてパケット径 が有効結晶粒径であると言える。一方，TF 材の場合，図 3 のように強い $\mathrm{RD} / /<110$ >を有する超微細繊維状結晶粒 組織が発達しているが，当然ながら焼戻し温度の $500^{\circ} \mathrm{C}$ で溝ロール圧延する過程で図 15(b)に示したように旧 $\gamma$ 粒 やその内部構造も $\mathrm{RD}$ に伸張する．超微細繊維状結晶粒は，これら内部構造の変化を伴いながら，粒の分断や転 位の回復をベースに形成すると考えられる(Kimura and Inoue, 2013). ここで, パケットが有効結晶粒と仮定すると， 図 14(b)の凹凸したき裂の進展は, 結晶粒界だけでなく, 図 15(b)に図示したような伸張パケット（パケット内の 微細粒は比較的同じ方位を有する）のへき開面やパケット境界に沿っていることが推測できる. 図 11 の微視き裂 の観察結果でも，き裂は結晶粒サイズというよりはもっと大きな単位で分岐しているのがわかる. なお，TF 材に おいて旧 $\gamma$ 粒やパケットを判別するのは困難であり，今後組織の詳細な解析が必要となるが，著者らが先に発表 (Kimura and Inoue, 2013)した溝ロール圧延の減面率, 組織, シャルピー衝撃特性の系統的関係から, 減面率の増加 によって旧 $\gamma$ 粒とともにパケットも伸展し，同時にブロック境界が RD に平行に揃いながら，超微細粒が形成す ることを確認している，よって，減面率が小さいと，ブロック境界が RDに平行に揃っていない組織となり，LD に平行な $\{100\}$ 面の存在確率が高くなる. その結果, 材料を破断させない方向へき裂を誘導することが難しくなる. 
事実，減面率が 38\%，52\%の場合は，主き裂を長手方向へ分岐させることができず，層状破壊が顕著に起こらな かったことで，シャルピー吸収エネルギを飛躍的に向上させることはできなかった.

\section{$4 \cdot 4$ TF 材の壊れにくさの発現機構}

一般的に，ノッチ底近傍の 3 軸応力状態において，LD と直角な方向の応力 $\sigma_{x x}$ が最大であり，その応力が脆性 破壊応力 $\sigma_{F}$ を超えることで, 脆性き裂は LD と平行に進展する. しかし, TF 材の場合, 脆性破壊応力は異方性を 有し，伸張した結晶粒の長手方向と平行な脆性破壊応力 $\sigma_{F / R D}$ は，それと直角な脆性破壊応力 $\sigma_{F \perp R D}$ に比べ著しく 大きい. また，図3,15(b)に模式的に示したように，弱い面（へき開面，結晶粒界，パケット境界）はLD とは垂 直およびさ45方向に多く存在する。よって, 図 5(b,c)に示した荷重低下は層状破壊を引き起こす微小き裂がノッ チ底近傍に発生したことが主因である．圧延前の初期結晶方位によっては，RD に平行になり難いパケット境界 も存在（図 15(b)参照）するため, 荷重方向あるいはそれと約 $45^{\circ}$ 方向に発生する主応力が駆動力となって層状破 壊を主導する微小き裂が LD と直角あるいは土45の角度で生じる可能性は高い.

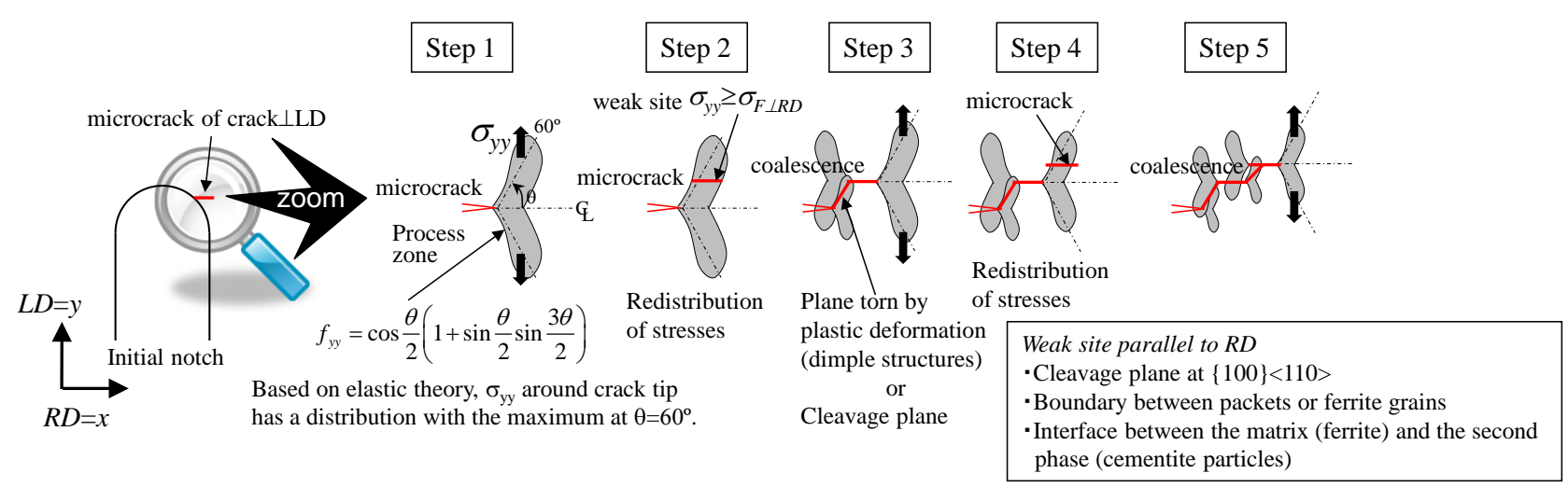

Fig. 16 Schematic illustration of fracture mechanism in TF sample.

図 16 は LD と直角な微小き裂 $c r a c k \perp L D （ 45^{\circ}$ の微小き裂 $\operatorname{crack} \angle 45^{\circ} \mathrm{LD}$ の場合もある）がノッチ底で発生し た場合を示す。ノッチやき裂を付与した勒性試験において，図10(e)のように RD に平行（すなわち，荷重負荷方 向 LD に直角) あるいは 45方向の微小 (脆性) き裂が発生すると, そのき裂は隣接するパケット境界等で停止し, これによってノッチ底近傍の応力は再配分され,一時的にその領域の応力は低下し, 応力分布は大きく変化する. その後, さらに押込むことによって, 荷重 $P$ の増加とともに発生した微小き裂端近傍において, 微小き裂と直角 方向の応力は $\theta= \pm 60^{\circ}$ で最大(日本材料学会, 1997) となる分布を持つ（図 16 の Step 1). よって, き裂端近傍のプロ セスゾーンにおいて微視組織が多くの損傷を受ける（超微小なき裂が生じる）中で， $\theta= \pm 60^{\circ}$ での最大垂直応力が 駆動力となって新たな微小き裂が発生する可能性が高い（図 16 の Step 2). 当然，発生したと同時にき裂の干涉


図 9 や他の温度での層状破面の観察結果から, 連結した面は微細なディンプル破面であり, 温度の低下と共にデ インプル破面の存在領域は少なくなっていた，すなわち，ジグザグき裂における層状破面において， step2 で生じ る $\mathrm{RD}$ に平行な脆性き裂は terrace に, step3 の連結で生じた破面が step に相当寸る. よって, 微小き裂の連結を 抑制する（すなわち，破壊抵抗を高める）ためにも, 微小き裂発生場所となる弱い面の空間分布だけでなく, 微 細粒組織で延性破壞を助長してき裂の進展を抑制することが強勒化にとって非常に重要となる. Step3の後は, 同 様なメカニズムでき裂は発生, 連結そして進展する. 複数の微小き裂が発生, 連結しても, 微細粒組織によって 十分な延性が担保されていれば, 複数のき裂の発生はむしろ個々のき裂端の応力を低下させるので, ノッチ底に おける応力集中を分散させる応力遮蔽効果によって材料の抵抗は大きくなる. 図 5(b)に示した TF 材の曲げ試験 において，荷重低下を伴いながら曲代荷重 $P$ が増加しているのは，その効果が適切に発揮しているためである. 特に, 試験温度 $23^{\circ} \mathrm{C}$ では $10 \mathrm{~mm}$ 押し込んでもその効果は失われていないのがわかる. このようなき裂の発生から 伝播する過程で破壊の駆動力は弱まり，材料そのものを破断させないことが可能となる．すなおち，材料全体で 力を受け止めていることになる，しかし，押込み量によって長手方向に分岐・成長したき裂やそれらき裂端近傍 
の微小き裂が増殖し, 温度低下によって組織の持つ壊れにくさの能力が失われると, $\mathrm{RD}$ と平行な応力 $\sigma_{x x}$ が駆動 力となってき裂は LD と平行な方向に進展する．結果的に，材料の抵抗，すなわち曲げ荷重 $P$ は一気に減少し材 料破断に至る.

ここで，もし弱い面が直線的に RD と平行にしか存在しなければ，発生した微小き裂端の応力の再配分が生じ る前に， RD に一直線上に沿ったき裂が瞬間的に大きく成長し，き裂の進展を抑制することができず，荷重の低 下はかなり大きくなることが想像できる，このような瞬間的な長いき裂の成長による大きな荷重低下は，異材接 合されたラミネート材(Pozuelo, et al., 2006)や繊維とマトリックスの界面で破壊する繊維強化複合材料に見られる (Ochiai, et al., 2001)．この場合, 界面の配向を適切に設計することで, 同じ繊維体積率であってもき裂の発生・進 展を変化させ, 急激な荷重低下 (すなわちき裂の進展長さ) を抑制し勒性を向上させることが可能となる(西川他, 2009). TF 材は，複合材料のような䋊維とマトリックス等の異種材料を結合するプロセスを必要とせず，単純な 棒圧延プロセスを通じて, 微細結晶粒の形態（粒径と粒形）と方位を精緻に制御することで破壊を制御したもの であり，今後の強勒特性向上を実現できる構造用金属材料の新たな方向性を示すと考えられる.

\section{5. 結 言}

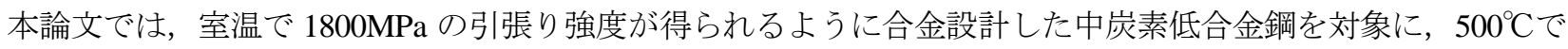
の多パス溝ロール圧延によって，強い $\alpha$ ファイバー集合組織を持ち，かつ結晶粒の短軸長さ $0.3 \mu \mathrm{m}$ の超微細緎維 状結晶粒組織を有する $14 \mathrm{~mm}$ 角 $\times 1000 \mathrm{~mm}$ 長さの棒鋼（TF 材）を創成し，引張り試験， 3 点曲げ試験，そして組 織観察を通じて, 初期ノッチ底からのき裂伝播挙動と組織の関係について検討を行った. その結果, 以下のよう な成果が得られた.

（1）脆性的に最大荷重 $P_{\text {max }}$ で直ちに破断する既存鋼（QT 材）と異なり，TF材では押し込み量 $u$ の増加と共に 荷重 $P_{1}$ で小さな荷重低下が生じ, その後, 多数の小さな荷重低下を伴いながら荷重 $P$ が増加し, そして緩

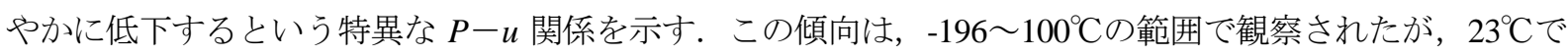
より顕著となった．また，最初に荷重が低下寸る $P_{1}$ は温度の減少とともに低下した．TF 材は超高強度で あっても脆性破壊的に破断しない機能を有することを確認した.

（2）微小き裂の発生はノッチ底周辺あるいはノッチ底より 0 . 数 $\mathrm{mm}$ 程離れた箇所であり, き裂は LD と直角 （cracks $\perp$ LD）あるいは $445^{\circ}$ の角度（cracks $\angle 45^{\circ} \mathrm{LD}$ ）を有し，その後ジグザグに長手方向に進展する層状 破壞挙動を示した．ジグザグき裂は，押込み荷重方向 LD と平行な面(step)における微細ディンプルと垂直 な面(terrace)における擬へき開で構成される．試験温度が-100ㄷ以下では， step/terrace のジグザグき裂は同 様に観察されたが, cracks $\angle 45^{\circ} \mathrm{LD}$ の微視き裂が主き裂に成長することで試験片は二つに破断した.

(3) 複数の微小き裂が発生, 連結しても, 微細粒組織によって十分な延性が担保されていれば, 複数のき裂の 発生はむしろ個々のき裂端の応力を低下させるので，ノッチ底における応力集中を分散させる応力遮蔽効 果によって材料の抵抗は大きくなる，微小き裂の連結を抑制する（すなわち，破壊抵抗を高める）ために も, 微小き裂発生場所となる弱い面の空間分布だけでなく, 微細粒組織で延性破壊を助長してき裂の進展 を抑制することが強勒化にとって非常に重要となる.

（4）単純な棒圧延プロセスを通じて，微細結晶粒の形態（粒径と粒形）と方位を精緻に制御することで，脆性 破壊しにくい材料の創出が可能であることを示すとともに，微視組織を制御して破壊を制御できる可能性 をメカニズムを含めて示した.

\section{謝 辞}

本研究では，溶解，鍛造，圧延による材料創製では檜原高明氏，黒田秀治氏，中里浩二氏，電子ビーム溶接に よる曲げ試験片作成では菅野勉氏，荒金吾郎氏，そして硬さ試験およびマクロ破面観察では保田友希江女史の助 力に負うところが大きい，ここに謝意を表する．また，本研究の一部は，科研費基盤 A「課題番号：26249107」 で行われたものである. 


\section{文献}

原田幸明，河西純一，動き出したレアメタル代替戦略，日刊工業新聞社 (2010).

Inoue, T. and Kimura, Y., Effect of initial notch orientation on fracture toughness in fail-safe steel, Journal of Materials Science, Vol. 48, No. 13 (2013), pp. 4766-4772.

井上忠信, 木村勇次, 超微細粒組織を活用した低炭素鋼の強勒化, 日本機械学会論文集 A 編, Vol.79, No.804 (2013), pp.1226-1238.

Inoue,T., Kimura, Y. and Ochiai, S., Shape effect of ultrafine-grained structure on static fracture toughness in low-alloy steel, Science and Technology of Advanced Materials, Vol. 13, No. 3 (2012), p. 035005.

Inoue,T., Kimura,Y. and Ochiai,S., Static fracture toughness in fail-safe steel, Scripta Materialia, Vol.65 (2011), pp. 552-555.

Inoue,T., Todaka,Y. and Horita, Z., Special issue on severe plastic deformation for production of ultrafine structures and unusual mechanics properties, Materials Transactions, Vol. 50, No. 1 (2009a), pp. 1-116.

Inoue,T., Yin, F. and Kimura, Y., Strain distribution and microstructural evolution in multi-pass warm caliber rolling, Materials Science and Engineering A, Vol. 466, No. 1-2 (2007), pp.114-122.

Inoue,T., Yin,F., Kimura,Y., Tsuzaki,K. and Ochiai,S., Delamination effect on impact properties of ultrafine-grained low-carbon steel processed by warm caliber rolling, Metallurgical and Materials Transactions A, Vol. 41, No. 2 (2009b), pp. 341-355.

Kimura, Y. and Inoue, T., Influence of warm tempforming on microstructure and mechanical properties in an ultrahigh-strength medium-carbon low-alloy steel, Metallurgical and Materials Transactions A, Vol. 44, No. 1 (2013), pp. 560-576.

Kimura,Y., Inoue, T., Yin, F. and Tsuzaki, K., Inverse temperature dependence of toughness in an ultrafine grain-structure steel, Science, Vol. 320, No. 5879 (2008), pp. 1057-1060.

Kum, D.W., Oyama,T., Wadsworth, J. and Sherby, O.D., The impact properties of laminated composites containing ultrahigh carbon(UHC) steels, Journal of the Mechanics and Physics of Solids, Vol. 31, No. 2 (1983), pp. 173-186.

物質・材料研究機構 (NIMS) 編, 近未来の鉄鋼材料を知るナノスケール解析（ナノ解析・ナノ分析）, No.3 (2002), 物質・材料研究機構.

三村宏, 町田進, 基礎材料強度学 (2005), p.117, 培風館.

Morris, J.W.Jr., Lee, C.S. and Guo, Z., The nature and consequences of coherent transformations in steel, ISIJ International, Vol. 43, No. 3 (2003), pp. 410-419.

西川雅章, 岡部朋永, 武田展雄, 短繊維強化プラスチックの破壊モードに及ぼす材料微視構造の影響, 日本機械 学会論文集 A 編, Vol. 75, No. 751 (2009), pp. 287-295.

Ochiai, S., Hojo, M., Schulte, K. and Fiedler, B., Nondimensional simulation of influence of toughness of interface on tensile stress-strain behavior of unidirectional microcomposite, Composites Part A: Applied Science and Manufacturing, Vol. 32, No. 6 (2001), pp. 749-761.

Pozuelo, M., Carreño, F. and Ruano, O.A., Delamination effect on the impact toughness of an ultrahigh carbon-mild steel laminate composite, Composites Science and Technology, Vol. 66, No. 15 (2006), pp. 2671-2676.

矢田浩, 鉄器時代はまだ終わらない一力学的性質から見た鉄と鋼一, ふえらむ, Vol. 1, No. 3 (1996), pp. 185-190. 日本材料学会編, 材料強度学 (1997), p.65, 日本材料学会.

\section{References}

Harada,K. and Kawanishi,J., Ugokidasita reametarudaigaesennryaku, Nikkan kougyou sinbunsya (2010), (in Japanese).

Inoue,T. and Kimura,Y., Effect of initial notch orientation on fracture toughness in fail-safe steel, Journal of Materials Science, Vol. 48, No. 13 (2013), pp. 4766-4772.

Inoue,T. and Kimura,Y., Toughening of low-carbon steel by ultrafine-grained structure, Transactions of the Japan Society of Mechanical Engineers Ser.A, Vol.79, No.804 (2013), pp.1226-1238. (in Japanese)

Inoue,T., Kimura,Y. and Ochiai,S., Shape effect of ultrafine-grained structure on static fracture toughness in low-alloy steel, Science and Technology of Advanced Materials, Vol. 13, No. 3 (2012), p. 035005.

Inoue,T., Kimura,Y. and Ochiai,S., Static fracture toughness in fail-safe steel, Scripta Materialia, Vol.65 (2011), pp. 552-555

Inoue,T., Todaka,Y. and Horita, Z., Special issue on severe plastic deformation for production of Ultrafine Structures and unusual mechanics properties, Materials Transactions, Vol. 50, No. 1 (2009a), pp. 1-116.

Inoue, T., Yin, F.and Kimura, Y.,Strain distribution and microstructural evolution in multi-pass warm caliber rolling, 
Materials Science and Engineering A, Vol. 466, No. 1-2 (2007), pp. 114-122.

Inoue,T., Yin,F., Kimura,Y., Tsuzaki,K. and Ochiai,S., Delamination effect on impact properties of ultrafine-grained low-carbon steel processed by warm caliber rolling, Metallurgical and Materials Transactions A, Vol. 41, No. 2 (2009b), pp. 341-355.

Kimura, Y. and Inoue, T., Influence of warm tempforming on microstructure and mechanical properties in an ultrahigh-strength medium-carbon low-alloy steel, Metallurgical and Materials Transactions A, Vol. 44, No. 1 (2013), pp. 560-576.

Kimura,Y., Inoue, T., Yin, F. and Tsuzaki, K., Inverse temperature dependence of toughness in an ultrafine grain-structure steel. Science, Vol. 320, No. 5879 (2008), pp. 1057-1060.

Kum, D.W., Oyama,T., Wadsworth, J. and Sherby,O.D., The impact properties of laminated composites containing ultrahigh carbon(UHC) steels,Journal of the Mechanics and Physics of Solids, Vol. 31, No. 2 (1983), pp. 173-186.

National Institute for Materials Science ed., Kinmirai no teltukouzairyou wo siru, nanosuke-rukaiseki(nanokaiseki • nanobunseki), No.3 (2002), National Institute for Materials Science (in Japanese).

Miura,H. and Machida,S, Kiso zairyou kyoudogaku (2005), p.117, Baifukan (in Japanese).

Morris,J.W. Jr., Lee,C.S. and Guo, Z., The nature and consequences of coherent transformations in steel, ISIJ International, Vol. 43, No. 3 (2003), pp. 410-419.

Nishikawa,M., Okabe,T. and Takeda,N., Effect of the Microstructure on the Fractare Mode of Short-Fiber Reinforced Plastic Composites, Transactions of the Japan Society of Mechanical Engineers Series A, Vol. 75, No. 751 (2009), pp. 287-295 (in Japanese).

Ochiai,S., Hojo,M., Schulte, K. and Fiedler, B., Nondimensional simulation of influence of toughness of interface on tensile stress-strain behavior of unidirectional microcomposite. Composites Part A: Applied Science and Manufacturing, Vol. 32, No. 6(2001), pp. 749-761.

Pozuelo, M., Carreño, F. and Ruano,O.A., Delamination effect on the impact toughness of an ultrahigh carbon-mild steel laminate composite, Composites Science and Technology, Vol. 66, No. 15 (2006), pp. 2671-2676.

Yata,H., Iron Age Still Continues : Iron and Steel Viewed from the Mechanical Properties, Ferrum, Vol. 1, No. 3 (1996), pp. 185-190 (in Japanese).

The Society of Materials Science ed., Strength and Fracture of Materials(1997), p.65, The Society of Materials Science(in Japanese). 